Preprint version of: Marco Rocca, Stepping stones over troubled waters. Recent legal evolutions and the reform of the Posting of Workers Directive, in N. Lillie and J. Arnholtz (eds.), Posted Work in the European Union. The Political Economy of Free Movement, Routledge, 167-184, 2020.

\title{
Stepping stones over troubled waters. Recent legal evolutions and the reform of the Posting of Workers Directive
}

\author{
Marco Rocca*
}

\section{Introduction}

After having been left aside as an unattainable goal during the years of the Barroso II Commission, the reform of the Posting of Workers Directive (PWD) was brought back to the centre stage by the political guidelines outlined by president Juncker in his speech in front of the European Parliament of 15 July 20141. At the time Mr. Juncker committed to a targeted review of the PWD to ensure that "[i]n our Union, the same work at the same place should be remunerated in the same manner". The EU Commission followed suit by presenting its proposal for a revision of the PWD on 8 March $2016^{2}$. Following the said political commitment, the proposal goes in the general direction of a better alignment of the working conditions of posted workers with those of local workers performing similar activities. In referring to this proposal in its State of the Union speech of 13 September 2017, president Juncker further highlighted the need for workers in the EU to earn "the same pay for the same work in the same place". A short time afterwards, the Committee on Employment and Social Affairs of the European Parliament approved its Report (19 October 2017), while the Council put forward its general approach on 24 October 2017. The agreed text was then adopted by the European Parliament in plenary on 30 May. The final adoption by the Council is expected on 21 June 2018.

In the past, the re-regulation of posting of workers at EU level had proved to be a particularly contentious issue, due to the conflicting interests between, broadly speaking, sending and receiving countries. This was perfectly epitomised by the difficulties of adopting a rather limited instrument such as the Enforcement Directive 3 (BERNACIAK, 2015:234), as well as by the reasoned opinions, better known as "yellow cards", issued by 11 national parliaments (or chambers of parliament) against the

\footnotetext{
* PhD, Researcher, National Centre for Scientific Research (CNRS, France) - University of Strasbourg, UMR 7354 DRES, mrocca@unistra.fr,$\underline{\text { https://marcorocca.wordpress.com . }}$

1 "A New Start for Europe: My Agenda for Jobs, Growth, Fairness and Democratic Change", Political Guidelines for the next European Commission, Opening Statement in the European Parliament Plenary Session, 15 July 2014.

${ }^{2} \operatorname{COM}(2016) 128$ final.

${ }^{3}$ Directive 2014/67/EU of the European Parliament and of the Council of 15 May 2014 on the enforcement of Directive 96/71/EC concerning the posting of workers in the framework of the provision of services and amending Regulation (EU) No 1024/2012 on administrative cooperation through the Internal Market Information System ('the IMI Regulation').
} 
reform of the PWD ${ }^{4}$. Those were raised in the context of the procedure introduced by the Lisbon Treaty with Protocol $n^{\circ} 2^{5}$, aimed at ensuring the respect of the principle of proportionality by EU legislation. The high political sensitivity of the issue is further highlighted by the decision of the Commission to completely sidestep the European social partners, not involving them in the consultation provided for by Article 154(2) of the Treaty of the Functioning of the European Union (TFEU), a point which was criticised by the Opinion of the European Economic and Social Committee ${ }^{6}$.

In light of these apparent tensions and considering the political orientations of both the EU Commission and the European Parliament majority, the question as to what made it possible to adopt an instrument going in the direction of more equal treatment between posted workers is a genuinely fascinating one. This Chapter explores one of the concurring aspects which allowed for the opening of the present window of opportunity. Notably, it explores which legal changes, at both EU and national level, provided the stepping stones towards the revision of the PWD. To this end, the Chapter first briefly considers the contents of the reform itself (Section 2). Then, in Section 3, it presents the legal evolutions at national and European level which have helped paving the way for the present reform of the PWD. In particular, the analysis focuses on three aspects: the case law of the Court of Justice of the European Union, changes in public procurement regulations and reforms at national level. These threads are also examined in an historical perspective by comparing them with the evolutions which led to the adoption of the original PWD in 1996. Section 4 is devoted to conclusions.

The reform of the PWD, starting point of our analysis, comes right on the verge of the tenth anniversary of the well-known Laval decision ${ }^{7}$, which, in the words of the Monti Report ${ }^{8}$ had revived "the divide between advocates of greater market integration and those who feel that the call for economic freedoms and for breaking up regulatory barriers is code for dismantling social rights protected at national level". In the series of decision concerning posting of workers delivered between 2007 and 2008', the Court of Justice of the European Union (hereinafter "CJEU" or "the Court") had famously interpreted the PWD not as a "floor" of rights but as a "ceiling" (EKLUND, 2008:566).

The Court denied the possibility for Member states to apply to posted workers' wages and working conditions going above the minima provided by the PWD or beyond the list of subjects included in the same instrument. It restricted the ability of Member States of unilaterally defining working conditions as covered by "public policy", and hence to apply them to posted workers. Furthermore, the Court strictly limited the collective agreements applicable to posted workers to those being universally or generally applicable, ruling out the possibility of company-based negotiations in the Host State, also in the name of a requirement of ex ante transparency for the posting undertaking. Trade Unions also saw

4 Bulgaria, Croatia, Czech Republic, Denmark, Estonia, Hungary, Latvia, Lithuania, Poland, Romania and Slovakia.

5 Protocol no. 2 on the application of the principles of subsidiarity and proportionality.

${ }^{6}$ Opinion of European Economic and Social Committee on Proposal for a Directive of the European Parliament and of the Council amending Directive 96/71/EC of the European Parliament and of the Council of 16 December 1996 concerning the posting of workers in the framework of the provision of services, 14 December 2016.

${ }^{7}$ CJEU, Case C-341/05, Laval un Partneri Ltd. v. Svenska Byggnadsarbetareförbundet, 18 December 2007

8 A New Strategy for the Single Market at the Service of Europe's Economy and Society, Report to the President of the European Commission José Manuel Barroso by Mario Monti, 9 May 2010.

${ }_{9}^{9}$ Beyond Laval, see CJEU, Case C-346/06, Dirk Rüffert v Land Niedersachsen, 3 April 2008; CJEU, Case C-319/06, Commission of the European Communities v Grand Duchy of Luxemburg, 19 June 2008. 
their ability to have recourse to collective action importantly curtailed, as this would only be possible to demand the application of minimum working conditions allowed by the PWD (as interpreted by the Court). Importantly, the CJEU considered that the legitimate objective of fighting against social dumping could be satisfied by applying the said minimum conditions ${ }^{10}$ (MALMBERG and SIGEMAN, 2008: 1136-1137 and 1144), so that any attempt to apply more favourable ones in the Host State would constitute a disproportionate restriction to the freedom to provide services protected by the Treaties.

The debate around "social dumping" already widespread after the EU enlargement of 2004 was reignited by these decisions. These also saw a clear-cut divide between "old" and "new" Member States (plus the United Kingdom) in the submissions to the Court, the former group broadly favouring the possibility of applying national standards to posted workers, the latter pleading for a stronger reading of the freedom to provide services (BERCUSSON, 2007). Whatever the actual meaning of "social dumping" for the different actors and in the different context (BERNACIACK, 2015a; ARNHOLTZ and ELDRING, 2015), posting of workers was perceived as allowing the posting undertaking to evade formal and informal national labour regulations, because of the combined impact of EU regulations and the objective difficulty of controlling and enforcing the application of national regulations. As described by BERNTSEN and LILLIE (2015), different undertakings deployed different strategies to take advantage of such a situation, by completely evading the application formal and informal rules (regulatory evasion); by carving out zones of exceptions to national rules on the basis of the specific regulations of posting of workers (regulatory arbitrage); or by manipulating regulatory frameworks to obtain cost advantages while formally respecting these local rules (regulatory conformance).

\section{The Reform}

To assess the actual change brought about by the revision of the PWD one has first to briefly analyse the content of the legal text, which should be adopted by the Council in its present form. However, it should be noted that the purpose of this Section is not to provide a full legal analysis of the revision. Instead, here I will focus on those aspects which appear to be more relevant to the debate surrounding the adoption of the reform itself, in particular as regards the issues arising from the decisions of the Court of Justice in 2007-2008.

The present revision should be seen as the second limb of the intervention initiated with the Enforcement Directive. The latter was meant to curb regulatory evasion by companies, by lowering the obstacles for the cross-border application of sanctions and by attacking practices such as the use of bogus posting. To do so, it included provisions facilitating the exchange of information and the administrative cooperation between national administrations, as well as a list of indicative factors to identify genuine posting. In light of the lack of political will (or feasibility) of reforming the PWD itself, the EU legislator focused on fraud and thus on curbing regulatory evasion.

With respect to this situation, the reform marks a fundamental shift in the approach, as it addresses the question of the wages and working conditions which should be applied to workers who are legally posted to another Member State. In doing so it brings the said wages and working conditions closer to those applicable to local workers, hence addressing the risks posed by regulatory arbitrage and conformance. Or, following a different taxonomy, the risk posed by legal social dumping (BERNACIAK, 2015: 230).

${ }^{10}$ Laval, $\$ \subseteq 75,103$ and 108. 
As mentioned in the Introduction, after it was first presented by the Commission the proposal received 11 (negative) reasoned opinions from national parliamentary chambers, through the procedure theoretically aimed at ensuring the respect of the subsidiarity principle by EU legislation. Notably, a number of national parliaments lamented that the proposal came too early after the adoption of the Enforcement Directive (SK, RO, LV, LT, EE), while many more criticised the reform on the basis of the loss of competitive advantage for posting undertakings, the excessive administrative burden and the impact on SME's (RO, LV, LT, HU, EE, CZ, CR, BG). The Danish parliament also sent a reasoned opinion, this one focused on one specific aspect of the proposal. Notably, this opinion criticised the fact that the proposal initially tabled by the EU Commission removed the reference to national law and/or practice in the context of the definition of remuneration.

Having reached the threshold of a third of national parliaments emitting a reasoned opinion against the proposal of the Commission the 'yellow card' procedure was triggered, according to the Protocol on the application of the principles of subsidiarity and proportionality. Therefore, the Commission had to decide to maintain, amend or withdraw the proposal, having also to justify its decision. The Commission responded on the 20 July 2016 with a Communication ${ }^{11}$, in which it maintained the proposal. Dealing with the question of the loss of competitive advantage, the Commission stated that "the proposal does not have the objective of aligning wages across Member States. The proposal merely ensures that mandatory rules on remuneration in the host Member State are applicable also to workers posted to that Member State".

Interestingly, the 'yellow card' procedure had previously been triggered in the context of a proposal by the Commission aimed at dealing with yet another fallout caused by the decisions of the Court of Justice in the cases of Laval and (equally infamous) Viking12. Indeed, the so-called "Monti II" proposal13 (BRUUN, BÜCKER and DORSSEMONT, 2012), dealing with the conflict between the right to take collective action and the freedoms of the internal market, had received negative reasoned opinions by 12 national parliaments / chamber of parliaments (BE, DK, FI, FR, LT, LU, MT, NL, PO, PT, SE, UK) (RoCCA, 2015a). However, in that case the Commission decided to withdraw the proposal ${ }^{14}$ and did not try its luck again with the same topic.

In analysing the content of the revision, I will refer to the legal text adopted by the plenary of the European Parliament on 29 May 2018 (hereinafter, "the Reform"). When necessary, I will compare this with the previous versions put forward along the legislative procedure, notably the original proposal tabled by the EU Commission (hereinafter "the Proposal"); the draft report of the Committee on Employment and Social Affairs of the European Parliament (hereinafter "the Committee Report"); the general approach agreed by the EPSCO Council (hereinafter "the Council Approach").

In light of their importance for determining the working conditions applicable to posted workers, I will focus on two areas of intervention: remuneration and collective agreements.

\footnotetext{
${ }^{11}$ Communication from the Commission to the European Parliament, the Council and the National Parliaments on the Proposal for a Directive amending the Posting of Workers Directive, with regard to the principle of subsidiarity, in accordance with Protocol No 2, COM(2016) 505 final.

12 CJEU, Case C-438/05, International Transport Workers' Federation and Finnish Seamen's Union v Viking Line ABP and OÜ Viking Line Eesti, 11 December 2007.

${ }_{13}$ Proposal for a Council Regulation on the exercise of the right to take collective action within the context of the freedom of establishment and the freedom to provide services, COM(2012) 130, 21 March 2012.

14 Brussels, 12 September 2012, Ares(2012)1058907.
} 


\section{a. Remuneration}

The Reform intervenes on the remuneration that should be applied to posted workers in a way which is coherent with the political statement by president Juncker: "the same work at the same place should be remunerated in the same manner". In this sense the reference to "minimum rates of pay" of Article 3(1)(c) of the PWD" 15 , is replaced by "remuneration". This is a common feature of all the previous iteration of the text. A study financed by the Commission and published in 2016 had in fact highlighted the confusion engendered by the very use of the concept "minimum rates of pay", considering that the different concept of "minimum wage" had a more widespread diffusion at national level (LHERNOUD et al., 2016).

When it comes to actually defining the meaning of the concept of "remuneration", the original text of the PWD in Article 3(1) refers to "the national law and/or practice of the Member State to whose territory the worker is posted" for the definition of "minimum rates of pay". The Reform maintains an essentially identical definition, while obviously replacing "minimum rates of pay" with "remuneration". Indeed, as it was mentioned before, the elimination of the reference to "national law and/or practice" (in the Proposal) had prompted the Danish yellow card mentioned above, so that it is not surprising that this formulation made its way back, first, in both the Council Approach and the Committee Report and, then, in the Reform.

On the other hand, the Reform introduces a new definition regarding the extension of the concept of remuneration, which will then cover "all the elements of remuneration rendered mandatory by national law, regulation or administrative provision, collective agreements or arbitration awards which in that Member State have been declared universally applicable or otherwise apply in accordance with Article 3 (8)". Recital 17 adds that, when comparing the remuneration applicable in the Home State and the one in the Host state, a global comparison should be carried out, thus taking into account the gross amount of remuneration, inclusive of the allowances specific to the posting.

The broadening of the concept of remuneration applicable to posted workers clearly goes in the direction of limiting the competitive advantage of posted workers vis-à-vis local workers. Notably, it reduces the possibility of regulatory conformance by posting undertaking, consisting in paying a given posted worker the lowest minimum wage applicable in the given Member State and/or sector, instead of the full remuneration to which he or she would normally be entitled in the Host State (ARNHOLTZ and ELDRING, 2015:84). As a caveat on this point, it should be noted here that the Court of Justice has stated, in $I s b i r^{16}$, that the ability of Member States to define the constituent elements of minimum rates of pay under the PWD should not "have the effect of impeding the free movement of services between Member States". One can find this approach mirrored in Recital 12 of the Proposal, which states that the application of national rules on remuneration "should not disproportionately restrict the crossborder provision of services". Importantly, this was not included in the Reform.

One further qualification should be added to this point. The Reform makes it compulsory for Member States to publish in the single official national website (created following the Enforcement Directive) the remuneration items applicable to posted workers. The Proposal, Committee Report and the

15 "Member States shall ensure that [...] undertakings referred to in Article 1(1) guarantee workers posted to their territory the terms and conditions of employment covering the following matters: [...] (c) the minimum rates of pay, including overtime rates".

16 CJEU, Case C-522/12, Tvfik Isbir, 7 November 2013, \$37. 
Council Approach are concordant on this point. All the various iteration of the text, though to a varying extent, consider that the lack of such transparency should be considered when evaluating eventual infringements by posting undertaking. The Reform states that, in case of incorrect or missing information, the circumstance "shall be taken into account $[\ldots]$ in determining penalties in the event of infringements". The Committee Report had proposed a stronger version of the same concept, exonerating the posting undertaking from any responsibility "if the information is not, or is incorrectly, provided on the single national official website prior to the commencement of the posting". The transparency requirement is also directly inspired by the case law of the Court of Justice, who, in Laval, criticised the Swedish system because it made "excessively difficult in practice" for the posting undertaking "to determine the obligations with which it is required to comply as regards minimum pay"17.

\section{b. Collective agreements}

The issue of the application of collective agreements to posted workers was also a particularly contentious one, following notably the Laval and Rüffert cases. In the former case, the Court had ruled out the possibility of using collective action to force the employer to sign a company-level agreement containing conditions going beyond and above the minimum level established by the PWD. In the latter, the Court first denied the possibility of applying collective agreements only covering a part of a given sector (public contracts) ${ }^{18}$. Second, it concluded that a country having a legal system for declaring collective agreements as universally applicable, as it was the case in Germany, cannot have recourse to different systems to ensure their applicability, such as referring to them in the awarding of public contracts $^{19}$.

The Reform addresses this very last point, by including, in the new Article 3(8), the possibility of applying generally applicable agreements or agreements concluded by the most representative organisations "in the absence of, or in addition to" universally applicable ones. This should be sufficient to avoid Rüffert-like situations in the future. That is, a situation in which a Member State characterised by a system for declaring collective agreements as universally applicable, is forbidden to applying generally applicable ones to posted workers, even when these might provide better wages and working conditions.

The most important change lies in the extension of the applicability of collective agreements to all sectors of the economy, whereas the PWD only mandated said application for the construction sector, leaving Member States free to extend this to other sectors ${ }^{20}$. The Reform, however, does not change the kind of collective agreements which can be applied to posted workers ${ }^{21}$, notably: collective agreements declared as universally applicable, collective agreement which are generally applicable to all similar undertakings in the geographical area and collective agreements concluded by most representative organizations at national level and which are applied throughout national territory.

\footnotetext{
${ }^{17}$ Laval, \$110. The CJEU had in fact raised a similar point already in Joined Cases C-369/96 and C-376/96, Arblade and Leloup, 23 November 1999, \43.

18 Rüffert, \$29.

${ }^{19}$ Ibidem, $\$ 27$.

${ }^{20}$ Article 3(10) of the PWD.

21 Article 3(1) and 3(8) of the PWD.
} 
The Reform thus confirms that decentralised systems of collective bargaining based on the autonomous extension of collective agreements through the threat of collective action will not be able to include posted workers in the future. To understand the full extent of this exclusion, one just has to look at the new rules concerning the time limit (12 months +6 of motivated extension) introduced in Article 3(1). Beyond this period, posted workers should be covered by "all the applicable terms and conditions of employment", hence going beyond and above the "hard core" of Article 3(1). This however only for the terms and conditions laid down by the very same sources applicable to posting in general. In the case of collective agreements this means universally applicable collective agreements and generally applicable ones within the meaning of Article 3(8). Thus, even after the 12+6 months, company based collective bargaining to cover posted workers in the Host State remains precluded.

This remains problematic, since in the past several years the EU institutions, and the Commission in particular, have been fostering reforms going in the direction of the decentralization of collective bargaining through the instruments of the EU economic governance (SCHULTEN and MULLER, 2013). Therefore, these systems remain exposed to posting strategies based on the formal respect of mandatory rules and the actual avoidance of industrial relations practices, being de facto forced to introduce systems for extension of collective agreement which would otherwise be alien to their national traditions (ARNHOLZ and ELDRING, 2015).

Finally, the Reform introduces a so-called "Monti clause" in Article 1(5). This clause, first appeared in the Regulation on the functioning of the internal market in relation to the free movement of goods among Member States 22 , should ensure that a specific piece of EU legislation does not affect the right to take collective action as well as the right to negotiate, conclude and enforce collective agreements. Both the Council Approach (Recital 11a) and the Committee Report (Recital 13d) included the clause among the Recitals, so that its "promotion" to the actual legal text seem to imply the will to give it a stronger legal effect ${ }^{23}$.

However, the potential impact of such a clause is, at best, difficult to assess. The restrictions to the exercise of fundamental (social) rights brought about by the case law of the Court of Justice, in cases such as Viking, Laval and Commission v Germany ${ }^{24}$, stem in fact from the interpretation of primary EU law (i.e. the Treaties). Indeed, in all these cases a fundamental social right (right to collective action, right to collective bargaining) was "balanced" by the Court of Justice against one of the fundamental freedoms of the internal market (freedom to provide services, freedom of establishment) protected by the Treaty on the Functioning of the EU. The exercise of the said fundamental rights ${ }^{25}$ was considered by the CJEU as constituting a restriction to the fundamental freedoms, and in all three cases the restriction was found to be disproportionate, going beyond what was necessary and/or proportionate to ensure the protection of workers in the given situation. Thus, the fundamental social right at stake had to bend the knee to the freedoms of the internal market. As such, it seems doubtful that an intervention at the level of secondary legislation (i.e. a Directive), such as the one included in the

\footnotetext{
${ }^{22}$ Council Regulation of 7 December 1998, OJ L337/8, 12 December 1998. The nickname "Monti clause" comes from the name of the, at the time, Commissioner for Internal Market, Mario Monti.

${ }^{23}$ As the Court of Justice has clearly stated, "the preamble to a Community act has no binding legal force". See CJEIU, Case C-134/08, Hauptrollamt Bremen v J. E. Tyson Parketthandel GmbH hanse j., 2 April 2009.

${ }^{24}$ CJEU, Case C-271/08, European Commission v Federal Republic of Germany, 15 July 2010.

25 In Viking this consisted in the concerted refusal to negotiate with an employer after a reflagging operation; Laval dealt with a blockade of a building site aimed at signing a company level collective agreement, whereas Commission v Germany was concerned with a collective agreement in the public sector establishing an occupational pension.
} 
Reform, might do much to change this situation (BRUUN, BÜCKER and DORSSEMONT, 2012:284-285; ROCCA, 2012:28-29).

\section{Stepping stones}

Having outlined (some of) the important areas of intervention of the Reform, I will now turn to the original question proposed in the Introduction. How was such a Reform possible at all in the context of the 2016-2018 European Union? In particular, which legal changes have contributed to make it possible to achieve a compromise which appeared as impossible just a few years before, all the while the EU is still dealing with its multiple crises.

First of all, when assessing the difficulties of delivering the reform of the PWD, one should keep in mind the historical perspective. Indeed, the adoption of the original Directive had not, in its turn, proved particularly simple for the European legislator. The PWD took almost six years of negotiations to be adopted, a period punctuated by three different proposals tabled by the EU Commission, leading up to a compromise, sometimes reached at the cost of legal clarity (ROCCA, 2015:113 and ff.). As such, this story provides an interesting analogy for analysing the favourable context which ultimately led to the adoption of a hotly debated piece of legislation.

In this sense, legal scholarship tends to focus on the role of the case law of the Court of Justice in paving the way for the reform. Notably, the decision in the Rush Portuguesa case ${ }^{26}$ has often been presented as the original impulse which set in motion the negotiations around the PWD (KOLEHMAINEN, 1998). Although the decision clearly did play an important role in the drafting of the directive, the precise nature of such a role is not straightforward. In his turn, EICHHORST (1998) traces the origin of the PWD back to the activity of the European Federation of Building and Wood Workers (EFBWWW) in the proposal for a directive on the liberalisation of public procurement. ${ }^{27}$ Furthermore, national reforms adopted during the negotiations of the PWD have also been considered as a fundamental impulse for the ultimate adoption of the Directive, as they lowered the incentives to oppose the adoption of the PWD itself (STREECK, 1998).

These "stepping stones", which led to the adoption of the original PWD, bear a striking similarity with the context of the reform which I have sketched above.

\section{a. Evolving Case Law}

Looking at the role played by the Court, commentators often highlighted how the said Rush Portuguesa decision played a fundamental role in kicking off the legislative process which led to the adoption of the PWD. Two fundamental points must be highlighted in this sense. In Rush, the Court for the first time 28 explicitly placed the phenomenon of posting of workers in the framework of the freedom to provide services. As stressed by NOVITZ and EvJu (2012:15), "the Court effectively established a new legal basis for the movement of workers". The Court considered that the workers employed by a Portuguese company and posted to France would return to their home country after the completion of their work. Hence, not gaining at any time access to the labour market of the host state, they should not

${ }^{26}$ CJEU, Case C-113/89, Rush Portuguesa Ld da Office national d'immigration, 27 March 1990.

27 Council Directive 89/440/EEC of 21 July 1989.

28 Tough some precedent was already on this line of reasoning, see Joined Cases 62 and 63/81 Société anonyme de droit français Seco et Société anonyme de droit français Desquenne \& Giral v Etablissement d'assurance contre la vieillesse et l'invalidité, 3 february 1982. 
fall under the free movement of workers. ${ }^{29}$ On the other hand, the Court threw a crumb of comfort, in answer to concerns about social dumping (GORMLEY, 1992) by stating that Member states were still free to extend the full extent of their legislation and/or collective agreements to all workers employed, even temporarily, on their territory. ${ }^{30}$ The negotiations of the PWD started a few months after this decision, as the first draft of the directive was presented by the Commission on 30 august 1991, 31 after a round of consultation with governments of the Member states and European social partners.

The two aspects we just highlighted of Rush Portuguesa had an important impact on the negotiations. First of all, the framing of the posting phenomenon in the free provision of services would shape the legal basis adopted for the PWD. This would lead to an instrument in principle aimed at facilitating the transnational provision of services, instead of (for instance) equal treatment of posted workers or the protection of working conditions. Second, the possibility left to Member States to extend the full range of their labour regulations to posted workers clearly created a default position which made opposing the PWD much less interesting for potential "exporters" of posted workers.

Turning to the present days, a specific decision deserves being mentioned first, as it essentially anticipated the whole reform in the field of remuneration. Indeed, in Säbköalojen ${ }^{32}$, the CJEU clarified the concept of "minimum rates of pay" used by Article 3(1) of the PWD. Following the reasoning of the Court, this concept covers not only the minimum wage per se but also the minimum wage applicable to specific categories of employees and the minimum hourly (or piece) rate, as well as the eventual daily and travel allowances at the same conditions applicable to local workers ${ }^{33}$. On the contrary, compensation paid by the employer to cover for the posted workers' accommodation, as well as meal vouchers, cannot be computed by the employer in the amount to be paid to the posted workers as "minimum rates of pay".

Read side by side with the innovations dealing with remuneration included in the Reform ${ }^{34}$, it is quite apparent how the case in question has clearly inspired the European legislator (VAN HoEK, 2018:482). The Council Approach went in fact even further, by proposing a specific Recital (12a) which would explicitly refer to the case law of the CJEU to identify the elements to be included in the remuneration applied to posted workers. Also, the importance awarded to the ex-ante transparency of the rules applicable to posted workers can be found already in Säbkäalojenn", where the Court considered that "to be enforceable against an employer which posts its employees to that Member State, those rules must be binding and must meet the requirements of transparency, which means, in particular, that they must be accessible and clear". In fact, as it was mentioned before, the requirement of "transparency" as to the working conditions applicable to posted workers was already present in earlier cases ${ }^{36}$.

If such a decision clearly went in the direction of closing the gap between wages applicable to posted workers and those enjoyed by local workers, it should be borne in mind that the cost advantage of the former stems sometimes to a much greater extent to differences in social security contributions (BERNTSEN and LILLIE, 2015:54-55). These remains payable in the Home State as long as the posting

\footnotetext{
${ }^{29}$ Rush Portuguesa, $\ 15$.

${ }^{30}$ Rush Portuguesa, $₫ 18$.

31 OJ C 225/6 of 30 august 1991.

32 CJEU, Case C-396/13, Sähköalojen ammattilittto ry v Elektrobudowa Spolka Akcyjna, 12 February 2015.

33 Ibidem, $\$ 70$.

34 See supra Section 2.a.

35 Sähköalojen, $₫ 40$.

${ }^{36}$ Laval, \$110, Arblade, \43.
} 
does not last for more than 24 months ${ }^{37}$. The affiliation of posted workers to the social security system of the Home State is proved by the A1 (formerly E101) certificate issued by the competent national authorities.

In this regard, a recent decision of the CJEU ${ }^{38}$ denied the authorities of the Host State the possibility of revoking autonomously the validity of an A1 certificate. Notably, the Court stated that even where it is found by the courts of the Host State that a specific situation does not fall under the rules provided by the EU framework for posting of workers, said courts cannot call into question the validity of the A1 certificate, and must address a request to this end to the competent authorities of the Home State ${ }^{39}$. This evidently has an important impact in terms of enforcement of social security rules, making it much more difficult and time consuming for national authorities in the Host State to control the application of said rules by posting undertaking.

Therefore, such a stance confirms the possibility of regulatory arbitrage based on different social security costs, making it possible to balance the "loss" suffered, as a consequence of the reform of the PWD, by posting undertakings on the side of wages and potentially shifting business strategy when it comes to the choice of a Home State.

Writing about the adoption of the PWD, BARNARD (2000:179) highlighted how the choice to refer to "minimum rates of pay" still allowed some competitive advantage for posting undertaking, thus constituting a compromise between the positions of the, broadly speaking, two groups of Member States (exporters and importers of posted workers). The shift entailed by the Reform might indeed mean that the quantum of competitive advantage will now be assured by differences in social security costs. The contours of the legal battle surrounding such strategies are in fact already been drawn in front of the Court of Justice. In a more recent case, the CJEU conceded that national courts may disregard A1 certificates awarded by the Member State of establishment of the posting undertaking if it finds that those were fraudulently obtained and "the issuing institution fails to take that evidence into consideration for the purpose of reviewing the grounds for the issue of those certificates" 40 .

\section{b. Public procurement}

If one looks back at the negotiations of the original PWD, those were preceded by the (failed) attempt, supported in particular by the European Federation of Building and Wood Workers (EFBWW) to include provisions related to social clauses in the regulation of public procurement (EICHHORST, 1998).

This refers to the debate around the inclusion of a binding social clause in the cited directive on liberalisation of public procurement. ${ }^{41}$ This clause, requiring public contracts to ensure the application of wages and working conditions equal to those prevailing at the place of work, was shaped similarly to ILO Convention no. $94^{42}$ (BRUUN, JACOBS and SCHMIDT, 2010). In the end the social clause was made

\footnotetext{
37 Regulation (EC) No 883/2004 of the European Parliament and of the Council of 29 April 2004 on the coordination of social security systems, Article 12. Although clarified, this rule should remain unchanged in the revision of the regulation on social security coordination, currently underway as part of the so-called "Mobility Package".

${ }^{38}$ CJEU, Case C-620/15, A-Rosa Flussschiff GmbH v Union de recouvrement des cotisations de sécurité sociale et d'allocations familiales (Urssaf) d'Alsace, 27 April 2017.

${ }^{39}$ Ibidem, $₫ 53$.

${ }^{40}$ CJEU, Case C-359/16, Ömer Altun and others v Openbaar Ministerie, 6 February 2018, \$61.

${ }^{41}$ Directive 89/440/eeC, oJ $1210 / 1$ of 21 July 1989.

42 ILO, Labour Clauses (Public Contracts) Convention, 1949 (no. 94), 29 June 1949.
} 
optional, leaving it to contracting authorities to decide whether or not to include it in the tender. ${ }^{43}$ The outcome falling short of the request put forward by the EFBWW, the same federation started lobbying for a different instrument, encompassing posting of workers in general (hence, not only in the context of public procurement) (EvJU and NOVITZ, 2013:9).

In its turn, the reform of the PWD was instead preceded by a successful reform of the Public Procurement Directive ${ }^{44}$ which saw the light in 2014. The new Directive includes stronger and clearer provisions about social clauses (BARNARD, 2017). Notably, Article 18(2) provides an obligation for Member States "to ensure that in the performance of public contracts economic operators comply with [...] social and labour law established by Union law, national law, collective agreements or by the international environmental, social and labour law provisions", while Article 70 allows contracting authorities to include special conditions for the performance of a contract, which may include "economic, innovation-related, environmental, social or employment-related considerations".

The question of the possibility of including the respect of collective agreements among the conditions for the performance of a contract was brought to the fore by the Rüffert case, which concerned a reference included in such conditions, to the minimum wage established by a collective agreement. As it was highlighted before, ${ }^{45}$ this was considered as going beyond the possibilities allowed by the PWD and hence in violation of the freedom to provide services. In reaction to the decision, several German Land decided to include the minimum wage applicable to public contracts directly in their regulations on public procurement (BÜCKER, HAUER and WALTER, 2011).

This was again tested in the Bundesdruckereit6 and RegioPost ${ }^{47}$ decisions, both dealing with transnational public procurement by German authorities. The first case did not in fact concern a posting situation, as the contract would have been completely performed in the Home State of the undertaking, as it concerned the provision of digital services. For this reason, the CJEU concluded against the applicability of the minimum wage. RegioPost originated instead from the refusal of an undertaking (established in another Member State) to guarantee the application of the minimum wage included among the conditions of performance to its eventual posted workers ${ }^{48}$. In this case the Court upheld the application of the minimum wage mandated by the regional law of the Rhineland Palatinate. With respect to Rüffert, the CJEU considered that such a wage was set by law, thus complaining with Article 3(1) of the PWD, and it was necessary and proportionate to protect posted workers, as no other minimum wage was applicable in the precise situation ${ }^{49}$. This decision was largely read as a correction to the Rüffert reasoning (PECINOVSKY, 2016), although a limited one when it comes to the role of collective bargaining (NoviTZ, 2018), as in RegioPost the Court appeared to show a preference for the direct indication of minimum wages in a legislative act (ROCCA, 2016).

At the very least, RegioPost clearly upheld the response strategy developed by German regional authorities, consisting in the inclusion of a legally mandated minimum wage for service providers in the context of public procurement. Considering the importance of public procurement (BARNARD, 2011),

\footnotetext{
${ }^{43}$ Directive 89/440/EEC, article 18 inserting a new article 22a into directive 71/305/EC.

44 Directive 2014/25/UE.

45 See supra Section 2.b.

${ }^{46}$ CJEU, Case C-549/13, Bundesdruckerei GmbH v Stadt Dortmund, 18 September 2014.

47 CJEU, Case C-115/14, RegioPost GmbH \& Co. KG v Stadt Landau in der Pfalz, 17 November 2015.

48 RegioPost, $\$ 24$.

${ }^{49}$ Ibidem, $\$ \$ 10$ and 21. Notably, the German federal minimum wage was not yet applicable to the facts of the case, and the sectoral collective agreement had recently been declared invalid.
} 
particularly in the construction sector, this change of approach in the context of a very relevant market (Germany), coupled with the new formulation of the Public Procurement Directive, went once again in the direction of limiting the possibilities for regulatory arbitrage, hence reducing the incentives to oppose the reform of the PWD.

\section{c. The National Level}

The long negotiations surrounding the original PWD witnessed an important slow-down after the second draft presented by the EU Commission in 1993. This was due to the difficulty in reconciling the position of those Member States favouring a stronger directive, which would apply from "day 0" of the posting, with the one of those favouring a "lighter" directive (notably Portugal and the UK) which would only be applicable to posted workers after a so-called "grace period" during which the Home State conditions would still apply. EICHHORST (1998: 20 and ff.) highlights how Member States, faced with such a deadlock at European level, decided to take action at the national one. Notably, the two largest "importers" of posted workers, which were, at the time just like in the present days, France and Germany, passed a strong national regulation for posted workers. On the specific issue of the "grace period", both the French ${ }^{50}$ and the German ${ }^{51}$ law decided in favour of the "zero day" option. This rapidly increased the incentives for the "exporters" side to reach an agreement on the PWD at European level, in order to pre-empt further regulation at the national one (STREECK, 1998:28-29).

Back to the present days, the appetite for a reform of the PWD seemed exhausted after the adoption of the Enforcement Directive. Once again, the apparent impossibility of reaching a compromise at European level appears to have re-ignited the interest of re-regulating the phenomenon at national level. This is particularly evident if one looks at the French law of $2015^{52}$, but it was also the by-product of the introduction of the federal statutory minimum wage in Germany. ${ }^{53}$ As it was just reminded, these two countries represent the two most important destinations for posted workers. The introduction of the German minimum wage was particularly relevant for those sectors which had no minimum wage at all before this measure, and which featured an important number of posted workers, such as the meat sector (LILLIE and WAGNER, 2015:168-169) 54 .

The French reform in its turn followed in the footsteps of the Säbköalojen decision ${ }^{55}$ (LHERNOUD and PALLI, 2017:123), by broadening the concept of "minimum rates of pay" applicable to posted workers. In particular, the reform requires posted workers to be paid, on top of minimum rates of pay and overtime pay, "wage supplements provided for by statutory provisions and collective agreements". Interestingly, and once again echoing Sähköalojen, in Italy the same was achieved by a change in enforcement practices, as the national labour inspectorate recently gave instruction to its inspectors to include in the definition of "minimum rates of pay" all the elements of remuneration, such as travel and posting allowances. ${ }^{56}$

\footnotetext{
50 Article 36 of the "loi Quinquennale", creating a new article 1341-5 in the labour Code (Code du travai).

51 Arbeitnehmer-entsendegesetz, German Bundesgesetzblatt, i, 1996, pp. 227 and ff., 29 february 1996.

52 Article 280, Statute $N^{\circ}$ 990-2015, amending Article L1262-4 of the French Labour Code.

${ }^{53}$ Minimum Wage Act of 11 August 2014.

54 The issue of low wages in the German meat sector made object of a complaint brought by Belgium to the European Commission. See BBC News, 9 April 2013, Belgium protests over German low pay in EU complaint. 55 See supra Section 3.a.

${ }^{56}$ Ispettorato Nazionale del Lavoro, Circolare n. 1/2017, p. 10.
} 
The French (and Italian) experiences evidently anticipated some of the effects of the reform of the PWD. In its turn, the German federal minimum wage closed some loopholes which allowed for business strategies based on the use of cheap labour through posting of workers. As it was the case for the negotiations of the original PWD, the re-regulation at national level reduced the attractiveness of the baseline "no reform" scenario at the European one, particularly for those Member States interested at maintaining as much as possible the competitive advantage awarded by the previous regulation to posting undertakings.

\section{Conclusions}

At the end this short analysis of concurring factors, as well as of their historical similarities, it is worth reflecting on the insights arising from the different elements I have tried to outline.

First, even discounting the obvious lawyers' bias, the case law of the Court of Justice seems once again to have, at least, played a relevant role in providing a window of opportunity for re-regulation (MAjOnE, 2005:155-156; De SOUSA, 2012:989). On the one hand, decisions such as Säbköalojen and RegioPost reduced the distance between working conditions (and notably, wages) applicable to posted workers and to local workers, as such limiting the possibilities to have recourse to business strategies based on regulatory arbitrage and/or regulatory conformance. On the other, the very presence of these decisions allowed the reform of the PWD to be presented as a mere codification of case law (KILPATRICK, 2012), thus reducing the ammunition at the disposal of its opponents.

However, these cases did not happen in a vacuum. Indeed, both cases we just mentioned vindicate strategies and decisions taken at national level. In particular, it is of utmost importance to highlight that, almost twenty years after the PWD, Sähköalojen was essentially the first case concerning posting of workers decided by the CJEU where the directive was invoked to protect actual workers' rights. Virtually all previous cases where the Directive was involved were instead concerned with the right of an undertaking not to respect a certain collective agreement and/or not to apply a certain level of wages and working conditions. What made possible this decision was the role of the Finnish trade unions at national level in supporting the claims by posted workers. In this perspective, one should also acknowledge the importance of having introduced, in Article 11(3) of the Enforcement Directive, an obligation for Member States to ensure that trade unions (as well as other associations or organisations) may engage on behalf or in support of posted workers, with their approval, "in any judicial or administrative proceedings" to enforce the obligations stemming from the PWD and the Enforcement Directive itself.

Concerning RegioPost, it was already mentioned how this decision followed a strategy undertaken at the level of German Länder to enforce minimum wages through regional regulations on public procurement, as a reaction to the outcome of the Rüffert case. Similarly, the importance of national response strategies is highlighted by the reforms enacted in relevant posting destinations, such as France and Germany, which closed loopholes and, in some ways, anticipated the reform of the PWD. As the story of the adoption of the original PWD, these insights confirm the importance of national actors and national strategies in shaping EU policy and legislation (EICHHORST, 1998).

Although the Reform has the evident merit of successfully concluding an actual, and previously unthinkable, revision of the PWD, it should also be noted that it still only address some of the issues arising from the 2007-2008 case law of the Court of Justice. Limiting ourselves to the topics analysed in the present Chapter, the intervention on remuneration surely helps clarifying a relevant element of the 
working conditions applicable to posted workers, thus dispelling the risk entailed by the concept of "minimum rates of pay" of limiting those to the very lowest minimum wage applicable in the given situation. Still, the Reform would do nothing (or, at best, very little) to solve the issues linked to the interaction between posting of workers and systems of collective bargaining based on decentralised agreements and/or lacking a system for the extension of the binding effect of collective agreements, as highlighted by the Laval case. Under the reformed PWD, these systems would still need to re-regulate the phenomenon at national level, introducing some form of extension of collective agreements (or minimum wages established by legislation) if they want to be able to cover posted workers at all.

\section{References}

K. Ahlberg (2013), "The age of innocence - and beyond", in S. Evju, Cross-Border Services, Posting of Workers and Multilevel Governance, Institutt for privaterett, 297-328.

J. ARNHOLTZ and L. ELDRING (2015), "Varying perceptions of social dumping in similar countries", in M. BERNACIAK (ed), Market Expansion and Social Dumping in Europe, Routledge, 80-96.

L. BERNTSEN and N. LILLIE (2015), Breaking the Law? Varietes of social dumping in a panEuropean labour market, in M. BERNACIAK (ed.), Market Expansion and Social Dumping in Europe, Routledge, 4360.

C. BARNARD (2000), EC Employment Law, Oxford University Press.

C. BARnARD (2011), "Using Procurement Law to Enforce Labour Standards", In G. DAVIDOv and B. LANGILLE (eds.), The Idea of Labour Law, Oxford University Press.

C. Barnard (2017), "To Boldly Go: Social Clauses in Public Procurement”, Industrial Law Journal, Vol. 46, No. 2, 208-244.

M. BERNACIAK (2015a), "Introduction: social dumping and the EU integration process", in M. BERNACIAK (ed), Market Expansion and Social Dumping in Europe, Routledge, 1-22.

M. Bernaciak (2015), Conclusion, in M. Bernaciak (ed), Market Expansion and Social Dumping in Europe, Routledge, 226-234.

M. BIAGI (1996), "Fortune smiles on the Italian EU Presidency: talking half-seriously about the Posted Workers and Parental leave directives", International Journal of Comparative Labour Law and Industrial Relations, 12, no. 2, 97-109.

B. Bercusson (2007), "The Trade Union Movement and the European Union: Judgment Day", European Law Journal, 13(3), 279-308.

L. BRENTSEN and N. LILLIE (2015), "Breaking the law? Varieties of social dumping in a pan-European labour market”, in M. BERNACIAK (ed), Market Expansion and Social Dumping in Europe, Routledge, 4360.

A. BÜCKER, M. HAUER and T. WALTER (2011), “Workers' rights and economic freedoms: symphony or cacophony? A critical analysis from a German perspective" in A. Bücker and W. Warneck (eds), Reconciling Fundamental Social Rights and Economic Freedoms after Viking, Laval and Rüffert, Nomos.

N. BRUUn, A. JACOBS and M. SCHMIDT (2010), "ILO Convention no. 94 in the afermath of the Rüffert Case", Transfer: european review of labour law and research, 16(4), 473-488 
N. Bruun, A. BÜCKer and F. Dorssemont (2012), "Balancing Fundamental Social Rights and Economic Freedoms: Can the Monti II Initiative Solve the EU Dilemma?", International journal of comparative labour law and industrial relations, 279-306.

P. C. DE SousA (2012), "Negative and Positive Integration in EU Economic Law: Between Strategic Denial and Cognitive Dissonance?”, German Law Journal, 13(8), 979-1012.

W. EichHorst (1998), "European Social Policy Between National and Supranational Regulation: Posted Workers in the Framework of Liberalized Services Provision”, MPifg Discussion Paper.

R. EKLund (2008), "A Swedish Perspective on Laval”, Comparative Labor Law \& Policy Journal, 29(4), $551-572$.

S. EvjU and T. NOVITZ (2013), "The evolving regulation : dynamics and Consequences", FORMULA Working Paper, 33, 1-89.

L. GORMLEY (1992), "freedom of establishment and freedom to Provide services. Workers and services distinguished”, European Law Review, 17, 63-67.

C. KilPATRICK (2012), "Internal Market Architecture and the Accommodation of Labour Rights: as Good as it Gets?”, European Journal of Social Law, 1, 1-26.

E. Kolehmainen (1998), "The Directive Concerning the Posting of Workers: Synchronizations of the Functions of National Legal Systems”, Comparative Labor Law \& Policy Journal, 20, 71-104.

J-P. LHERNOULD et al. (2016), Study on wage setting systems and minimum rates of pay applicable to posted workers in accordance with Directive 96/71/EC in a selected number of Member States and sectors, Contract No VC/2015/0334 Final report.

J-P. Lhernould and B. PALLI (2017), "Posted workers remuneration: Comparative study in nine EU countries and four sectors", Maastricht Journal of European and Comparative Law, 24(1), 108-126.

N. LILLIE and I. WAGNER (2015), "Subcontracting, insecurity and posted workers: evidence from construction, meat processing, and ship building", in J. Drahokoupil (ed), The outsourcing challenge: organizing workers across fragmented production networks, Brussels, ETUI, 157-174.

G. MAjOnE (2005), Dilemmas of European Integration, Oxford University Press.

J. Malmberg and T. Sigeman (2008), "Industrial actions and EU economic freedoms: The autonomous collective bargaining model curtailed by the European Court of Justice", Common Market Law Review, 45(4), 1115-1146.

T. NOviTZ (2018), "Collective Bargaining and Social Dumping in Posting and Procurement: What Might Come from Recent Court of Justice Case Law and the Proposed Reform of the Posted Workers Directive?", in A. SANCHEZ Graells (ed), Smart Public Procurement and Labour Standards Pushing the Discussion after RegioPost, Bloomsbury, 215-244.

P. Pecinovsky (2016), "Evolutions in the Social Case Law of the Court of Justice. The Follow-up Cases of the Laval Quartet: ESA and Regiopost", European Labour Law Journal, 7(2), 294-309.

M. RocCA (2016), “Arrêt « RegioPost » : marché public et salaire minimal fixé par une entité régionale”, Journal de droit européen, 2, 57-58.

M. RoccA (2015), Posting of Workers and Collective Labour Law: There and Back Again. Between Internal Market and Fundamental Rights, Intersentia, 2015.

M. RocCA (2015a), “Le droit de grève et l’Union Européenne en période d'austérité: la proposition "Monti II" et ses cartons jaunes", Interventions économiques / Papers in Political Economy, 52. 
RoccA (2012), “The Proposal for a (so-called) 'Monti II' Regulation on the Exercise of the Right to Take Collective Action within the Context of the Freedom of Establishment and the Freedom to Provide Services", European Labour Law Journal, 1, 19-28.

T. SCHUlteN and T. MÜLLER (2013), "A New European Interventionism? The Impact of the New European Economic Governance on Wages and Collective bargaining", in D. Natali and B. Vanhercke (eds), Social Developments in the EU 2012, ETUI-OSE Publications, 181-214.

W. STREECK (1998), "The internationalization of industrial relations in Europe: prospects and problems", Working Paper Series in European Studies, no. 1.

A. VAn HoEK (2018), "Re-Embedding the Transnational Employment Relationship: A Tale about the Limitations of (EU) Law?”, Common Market Law Review 55, no. 2, 449-87. 